\title{
Hubungan Tingkat Kecukupan Zat Gizi dengan Status Gizi Anak Sekolah Dasar di SD Negeri 48 Kota Ternate Tahun 2019
}

\author{
Indriana Djamaluddin ${ }^{1}$, Andiani ${ }^{2 凶}$, dan Diah Merdekawati Surasno ${ }^{2}$ \\ 1 Mahasiswa Fakultas Ilmu Kesehatan, Universitas Muhammadiyah Maluku Utara. Ternate, Indonesia. \\ 2 Staf Pengajar Fakultas Ilmu Kesehatan, Universitas Muhammadiyah Maluku Utara. Ternate, Indonesia. \\ Email : andianimahbub@gmail.com \\ Korespondensi : Andiani, Universitas Muhammadiyah Maluku Utara. Ternate, Indonesia, \\ Email : andianimahbub@gmail.com
}

\begin{abstract}
ABSTRAK
Berdasarkan catatan Badan Kesehatan Dunia (WHO) overweight dan obesitas merupakan faktor risiko penyebab kematian nomor lima. Sedikitnya 2,8 juta penduduk meninggal per tahun akibat dari overweight dan obesitas. Ada 42 juta anak mengalami obesitas dan 35 juta diantaranya berasal dari Negara-negara berkembang. Di seluruh dunia prevalensi obesitas anak meningkat dari 4,2\% pada tahun 1990 menjadi $6,7 \%$ pada tahun 2010. Di Indonesia orang yang mengalami berat badan lebih (overweight) mencapai 21,7\% dan terus meningkat setiap tahunya (WHO, 2011). Trend ini diperkirakan akan mencapai 9,1\% atau 60 juta, pada tahun 2020. Untuk mengetahui hubungan antara tingkat kecukupan energi dan protein, kebiasaan sarapan, frekuensi makanan jajan, dan jumlah uang jajan dengan status gizi siswa SD Negeri 48 Kota Ternate Tahun 2019. Jenis penelitian ini adalah penelitian observasi analitik, dengan desain cross sectional study. Penelitian ini dilaksanakan di SD Negeri 48 Kota Ternate dengan jumlah sampel 81 responden (Total Sampling). Hasil analisis menunjukkan bahwa semua variabel yang diteliti tidak ada hubungan antara tingkat kecukupan Energi $(p=0,695)$ dan hubungan antara tingkat kecukupan protein $(\mathrm{p}=0,767)$ untuk variabel frekuensi makanan jajan $(\mathrm{p}=1,000)$ kebiasaan sarapan $(\mathrm{p}=1,000)$, dan uang jajan $(\mathrm{p}=1,000)$ dengan status gizi anak sekolah dasar SD Negeri 48 Kota Ternate Tahun 2019. Berdasarkan hasil penelitian yang telah dilakukan maka disarankan kepada orang tua siswa untuk memberikan peningkatan pengetahuan tentang gizi terutama tentang memilih jajanan serta mempraktekanya dalam kehidupan sehari-hari agar menjadi perilaku yang dapat ditiru oleh anak.
\end{abstract}

Keyword: Status Gizi, Kecukupan Energi, Protein, Sarapan Pagi, Frekuensi Makanan Jajanan, Uang Jajan

\section{PENDAHULUAN}

World Health Organization (WHO) menyatakan bahwa gizi adalah pilar utama dari kesehatan dan kesejahteraan sepanjang siklus kehidupan. Upaya peningkatan status gizi untuk pembangunan sumber daya manusia yang berkualitas pada hakekatnya harus dimulai sedini mungkin, salah satunya anak usia sekolah (Djamarah, 2006).

Berdasarkan catatan Badan Kesehatan Dunia (WHO) overweight dan obesitas merupakan faktor risiko penyebab kematian nomor lima. Sedikitnya 2,8 juta penduduk meninggal per tahun akibat dari overweight dan obesitas. Overweight dan obesitas ini memiliki angka kematian yang tinggi didunia dibandingkan dengan underweight. Ada 42 juta anak mengalami obesitas dan 35 juta diantaranya berasal dari Negara-negara berkembang. Di seluruh dunia prevalensi kegemukan dan obesitas anak meningkat dari 4,2\% pada tahun 1990 menjadi 6,7\% pada tahun 2010.

Di Indonesia orang yang mengalami berat badan lebih (overweight) mencapai 21,7\% dan terus meningkat setiap tahunya (WHO, 2011). Trend ini diperkirakan akan mencapai 9,1\% atau 60 juta, pada tahun 2020 (Devi, 2011). Gizi lebih maupun gizi kurang dapat terjadi pada semua kalangan umur, anak-anak usia sekolah, remaja, maupun dewasa, namun yang sering terjadi pada tahun pertama kehidupan, pada usia sekolah. Status gizi anak sekolah sangat ditentukan oleh konsumsi pangan yang seimbang, selain peran orang tua, kesadaran anak sekolah dasar juga sangat diperlukan (Devi, 2011). Secara garis besar faktor lingkungan social sangat mempengaruhi konsumsi makan anak (Suryabrata, 
2010). Konsumsi kebiasaan makanan sehari-hari anak Indonesia menunjukkan gambaran poor dietery diversity dengan konsumsi yang rendah pada protein dan vitamin, tetapi tinggi konsumsi karbohidrat . Penelitian di Negara maju juga menyatakan prevalensi anak yang melewatkan sarapan berkisar antara 12-34\% (Ilyatun dkk, 2014).

Pada usia sekolah terjadi kecepatan pertumbuhan dan perkembangan fisik, mental, emosional serta sosial. Pada masa ini banyak masalah yang berdampak negatif terhadap kesehatan anak usia sekolah sehingga status gizi anak tersebut cenderung gizi kurang atau justru obesitas. Komposisi tubuh anak usia sekolah dasar juga mulai berubah. Komposisi lemak meningkat setelah anak berusia 6 tahun (Damayanti, dkk 2006). Gizi yang cukup, secara bertahap memainkan peran yang penting selama usia sekolah untuk menjamin bahwa anak-anak mendapatkan pertumbuhan, perkembangan dan kesehatan yang maksimal.

Anak sekolah biasanya mempunyai kebiasaan jajan makanan tinggi kalori yang rendah serat, dan terbiasa melewatkan sarapan beresiko 3 kali lebih tinggi untuk mengkonsumsi jajanan dan sulit mengontrol nafsu makan mereka sehingga menyebabkan obesitas (Kral, 2011). Apalagi 95\% anak diberi uang saku oleh orang tuanya sehingga kemungkinan untuk membeli makanan jajanan lebih tinggi (Depkes RI, 2011).

Jajanan biasanya didominasi dengan kandungan kerbohidrat yang tinggi dan hanya sedikit mengandung protein, vitamin, atau mineral. Makanan sampah (junk food) termasuk dalam makanan jajanan, berwujud snack ringan yang seringkali sengaja ditambahkan BTM (Bahan Tambahan Makanan) dengan tujuan untuk memperbaiki aroma, tekstur, rasa, penampakan, serta umur simpan makanan (Istiyani, 2013).

Menurut data RISKESDAS tahun 2013, secara nasional prevalensi status gizi pada anak umur 612 tahun pada kategori normal 70\%. Prevalensi kurus menurut (IMT/U) pada anak umur 6-12 tahun adalah $11,2 \%$, terdiri dari $4 \%$ sangat kurus dan 7,2\% kurus. Prevalensi status gizi gemuk pada anak umur 6-12 tahun secara nasional masih tinggi yaitu 18,8\% yang terdiri dari gemuk 10,8\% dan sangat gemuk (obesitas) 8,8\%. (Kemenkes, 2013). Berdasarkan data dari Dinas Kesehatan Kota Ternate Tahun 2016 menunjukan bahwa yang termasuk dalam wilayah kerja Puskesmas Siko dengan status gizi kategori gemuk yaitu tertinggi sebanyak 5 siswa, kurus 2 siswa, dan normal 851 siswa. Dan pada Tahun 2017 menunjukan bahwa di wilayah kerja Puskesmas Siko dengan status gizi kategori gemuk sebanyak 8 siswa, kurus 10 siswa, dan normal 875 siswa. (Dinas Kesehatan Kota Ternate Tahun 20162017). Data dari bagian kesiswaan SD Negeri 48 Kota Ternate yang bertempat di Kelurahan Akehuda Kecamatan Kota Ternate Utara di peroleh jumlah siswa keseluruhan 226 siswa (Data kesiswaan SD Negeri 48 Kota Ternate, 2018). Dan berdasarkan hasil observasi pemantauan status gizi pada 10 orang siswa di SD Negeri 48 Kota Ternate terdapat 4 orang siswa kurus, 1 orang siswa gemuk, dan 5 orang siswa normal.

\section{METODE PENELITIAN}

Jenis penelitian ini adalah penelitian observasi analitik, dengan desain cross sectional study. Lokasi penelitian di SD Negeri 48 Kota Ternate, dengan populasi adalah seluruh siswa dan siswi di SD Negeri 48 Kota Ternate sebanyak 226 siswa pada tahun 2019 (Bulan Januari). Sedangkan Sampelnya adalah 81 siswa dan siswa kelas IV dan Kelas V (total sampling). Menggunakan analisis univariat dan analisis bivariat menggunakan uji Chi-Square.

\section{HASIL}

\subsection{Analisis Univariat}

\subsubsection{Distribusi Responden Berdasarkan Kelas}

Tabel 1. Distribusi Responden Berdasarkan Kelas Di SD Negeri 48 Kota Ternate Tahun 2019

\begin{tabular}{ccc}
\hline Kelas & $\mathbf{N}$ & $\mathbf{\%}$ \\
\hline 4 & 38 & 48,1 \\
5 & 42 & 51,9 \\
\hline Jumlah & $\mathbf{8 1}$ & $\mathbf{1 0 0}$ \\
\hline
\end{tabular}

Sumber : Data Primer, 2019

Tabel 1, menunjukan bahwa distribusi respoden berdasarkan kelas yang tertinggi kelas $\mathrm{V}$ sebanyak 42 responden $(51,9 \%)$ dan terendah kelas IV berjumlah 38 responden $(48,1 \%)$. 


\subsubsection{Disribusi Respoden Berdasarkan Umur}

Tabel 2, menunjukan bahwa distribusi responden berdasarkan golongan umur yang tertinggi golongan umur 10 tahun sebanyak 40 responden $(49,4 \%)$ dan yang terendah pada golongan umur 12 tahun sebanyak 1 responden $(1,2 \%)$.

Tabel 2. Distribusi Responden Bedasarkan Umur Siswa Di SD Negeri 48 Kota Ternate Tahun 2019

\begin{tabular}{ccc}
\hline $\begin{array}{c}\text { Umur Siswa/Siswi } \\
\text { (Tahun) }\end{array}$ & $\mathbf{N}$ & $\mathbf{\%}$ \\
\hline 8 & 4 & 4,9 \\
9 & 17 & 21,0 \\
10 & 40 & 49,4 \\
11 & 19 & 23,5 \\
12 & 1 & 1,2 \\
\hline Jumlah & $\mathbf{8 1}$ & $\mathbf{1 0 0}$ \\
\hline
\end{tabular}

Sumber : Data Primer, 2019

\subsubsection{Distribusi Responden Berdasarkan Jenis Kelamin}

Tabel 3. Distribusi Responden Berdasarkan Jenis Kelamin Siswa Di SD Negeri 48 Kota Ternate Tahun 2019.

\begin{tabular}{ccc}
\hline Jenis Kelamin & N & \% \\
\hline Laki-Laki & 46 & 56,8 \\
Perempuan & 35 & 43,2 \\
\hline Jumlah & $\mathbf{8 1}$ & $\mathbf{1 0 0}$ \\
\hline
\end{tabular}

Sumber : Data Primer, 2019

Tabel 3, menunjukkan distribusi responden berdasarkan jenis kelamin yang tertinggi pada siswa dan siswi yang berjenis kelamin laki-laki sebanyak 46 responden $(56,8 \%)$ dan yang terendai berjenis kelamin perempuan sebnyak 35 responden $(43,2 \%)$

\subsubsection{Distribusi Responden Berdasarkan Tingkat Konsumsi Energi}

Tabel 4. Distribusi Responden Berdasakan Tingkat Konsumsi Energi Siswa Di SD Negeri 48 Kota Ternate Tahun 2019

\begin{tabular}{ccc}
\hline Tingkat Konsumsi Energi & $\mathbf{N}$ & $\mathbf{\%}$ \\
\hline Baik & 58 & 71,6 \\
Kurang & 23 & 28,4 \\
\hline Jumlah & $\mathbf{8 1}$ & $\mathbf{1 0 0}$ \\
\hline
\end{tabular}

Sumber : Data Primer, 2019

Tabel 4, menunjukkan bahwa distribusi responden berdasarkan tingkat konsumsi energi yang tertinggi pada siswa dan siswi yang tingkat kecukupan energinya baik sebanyak 58 responden $(71,6 \%)$ dan yang terendah tingkat konsumsi energinya kurang sebanyak 23 responden $(28,4 \%)$.

\subsubsection{Distribusi Responden Berdasarkan Tingkat Konsumsi Protein}

Tabel 5. Distribusi Responden Berdasarkan Tingkat Konsumsi Protein Siswa

Di SD Negeri 48 Kota Ternate Tahun 2019

\begin{tabular}{ccc}
\hline $\begin{array}{c}\text { Tingkat Konsumsi } \\
\text { Protein }\end{array}$ & $\mathbf{N}$ & $\mathbf{\%}$ \\
\hline Baik & 61 & 75,3 \\
Kurang & 20 & 24,7 \\
\hline Jumlah & $\mathbf{8 1}$ & $\mathbf{1 0 0}$
\end{tabular}

Tabel 5, menunjukkan bahwa distribusi responden berdasarkan tingkat konsumsi protein yang tertinggi pada siswa dan siswi yang tingkat kecukupan proteinnya baik sebanyak 61 responden $(75,3 \%)$ dan yang terendah pada siswa dan siswi yang tingkat konsumsi proteinnya kurang sebanyak 20 responden $(24,7 \%)$

\subsubsection{Distribusi Responden Berdasarkan Kebiasaan Sarapan}

Tabel 6, menunjukkan bahwa distribusi responden berdasarkan kebiasaan sarapan pagi yang tertinggi pada siswa dan siswi yang memiliki kebiasaan sarapan pagi baik sebanyak $59(72,8 \%)$ dan terendah yang memiliki kebiasaan sarapan pagi kurang sebanyak 22 responden $(27,2 \%)$. 
Tabel 6. Distribusi Responden Berdasarkan Kebiasaan Sarapan Siswa Di SD Negeri 48 Kota Ternate Tahun 2019

\begin{tabular}{ccc}
\hline Kebiasaan Sarapan & $\mathbf{N}$ & $\mathbf{\%}$ \\
\hline Baik & 59 & 72,8 \\
Kurang & 22 & 27,2 \\
\hline Jumlah & $\mathbf{8 1}$ & $\mathbf{1 0 0}$
\end{tabular}

Sumber : Data Primer, 2019

\subsubsection{Distribusi Responden Berdasarkan Jumlah Uang Jajan}

Tabel 7. Distribusi Responden Berdasarkan Jumlah Uang Jajan Siswa Di SD Negeri 48 Kota TernateTahun 2019

\begin{tabular}{ccc}
\hline Uang Jajan & $\mathbf{N}$ & $\mathbf{\%}$ \\
\hline Cukup (>Rp.5.000) & 80 & 98,8 \\
Kurang (<Rp.5.000) & 1 & 1,2 \\
\hline Jumlah & $\mathbf{8 1}$ & $\mathbf{1 0 0}$ \\
\hline
\end{tabular}

Sumber : Data Primer, 2019

Tabel 7, menunjukkan bahwa distribusi responden berdasarkan jumlah uang jajan yang tertinggi pada siswa dan siswi yang memiliki uang jajan cukup sebanyak 80 responden $(98,8 \%)$ dan terendah yang memiliki uang jajan kurang sebanyak 1 responden $(1,2 \%)$.

\subsubsection{Distirbusi Responden Berdasarkan Frekuaensi Makanan Jajanan}

Tabel 8. Distribusi Responden Berdasarkan Frekuensi Makanan Jajan Siswa Di

SD Negeri 48 Kota Ternate Tahun 2019

\begin{tabular}{ccc}
\hline $\begin{array}{c}\text { Frekuensi Makanan } \\
\text { Jajan }\end{array}$ & $\mathbf{N}$ & $\mathbf{\%}$ \\
\hline Baik & 18 & 22,2 \\
Kurang & 63 & 77,8 \\
\hline Jumlah & $\mathbf{8 1}$ & $\mathbf{1 0 0}$ \\
\hline
\end{tabular}

Sumber : Data Primer, 2019

Tabel 8, menunjukkan bahwa distribusi responden berdasarkan frekuensi makanan jajanan yang tertinggi pada siswa dan siswi yang memiliki frekuensi makanan jajanan kurang sebanyak 63 responden $(77,3 \%)$ dan yang terendah yang memiliki frekuensi jajanan baik sebanyak 18 responden $(22,2 \%)$.

\subsubsection{Distribusi Responden Berdasarkan Status Gizi}

Tabel 9. Distribusi Responden Berdasarkan Status Gizi Siswa Di SD Negeri 48 Kota Ternate Tahun 2019

\begin{tabular}{ccc}
\hline Status Gizi & N & \% \\
\hline Tidak Malnutrisi & 61 & 75,3 \\
Malnutrisi & 20 & 24,7 \\
\hline Jumlah & $\mathbf{8 1}$ & $\mathbf{1 0 0}$
\end{tabular}

Sumber : Data Primer, 2019

Tabel 9 menunjukkan bahwa distribusi respoden berdasarkan status gizi yang tertinggi pada siswa dan siswi yang memiliki status gizi tidak malnutrisi sebanyak 61 responden $(75,3 \%)$ dan yang terendah yang memiliki status gizi malnutrisi sebanyak 20 responden $(24,7 \%)$.

\subsection{Analisis Bivariat}

\subsubsection{Hubungan Tingkat Konsumsi Energi Dengan Status Gizi Anak Sekolah Dasar}

Tabel 10 menunjukkan bahwa dari 81 responden terdapat tingkat kecukupan energy baik dengan kategori status gizi tidak malnutrisi pada siswa sekolah dasar sebanyak 43 responden (43\%) dan malnutrisi 15 responden (18,5\%) sedangkan responden yang tingkat kecukupan energi kurang dengan kategori status gizi tidak malnutrisi pada siswa sekolah dasar sebanyak 18 responden $(22,2 \%)$ dan malnutrisi sebanyak 5 responden $(6,2 \%)$. 
Tabel 10. Analisis Hubungan Tingkat Kecukupan Energi Dengan Status Gizi Siswa Di SD Negeri 48 Kota Ternate Tahun 2019

\begin{tabular}{|c|c|c|c|c|c|c|}
\hline \multirow{3}{*}{$\begin{array}{c}\text { Tingkat Kecukupan } \\
\text { Energi }\end{array}$} & \multicolumn{4}{|c|}{ Status Gizi } & \multirow{2}{*}{\multicolumn{2}{|c|}{ Total }} \\
\hline & \multicolumn{2}{|c|}{$\begin{array}{c}\text { Tidak } \\
\text { malnutrisi }\end{array}$} & \multicolumn{2}{|c|}{ Malnutrisi } & & \\
\hline & $\mathbf{n}$ & $\%$ & $\mathbf{n}$ & $\%$ & $\mathbf{n}$ & $\%$ \\
\hline Baik & 43 & 53,1 & 15 & 18,5 & 58 & 71,6 \\
\hline Kurang & 18 & 22,2 & 5 & 6,2 & 23 & 28,4 \\
\hline Jumlah & 61 & 75,3 & 20 & 24,7 & 81 & 100 \\
\hline \multicolumn{7}{|c|}{$p=0,695$} \\
\hline
\end{tabular}

Sumber : Data Primer, 2019

Berdasarkan hasil uji statistic Chi-Square diperoleh nilai $\mathrm{p}=0,695<0,05$ sehingga hipotesis H0 diterima dan $\mathrm{H} 1$ di tolak berarti tidak ada hubungan antara tingkat kecukupan energi dengan status gizi siswa Sekolah Dasar Negeri 48 Kota Ternate Tahun 2019.

\subsubsection{Hubungan Tingkat Konsumsi Protein Dengan Status Gizi Anak Sekolah Dasar}

Tabel 11. Analisis Hubungan Tingkat Kecukupan Protein Dengan Status Gizi Siswa

Di SD Negeri 48 Kota Ternate Tahun 2019

\begin{tabular}{|c|c|c|c|c|c|c|}
\hline \multirow{3}{*}{$\begin{array}{c}\text { Tingkat Kecukupan } \\
\text { Protein }\end{array}$} & \multicolumn{4}{|c|}{ Status Gizi } & \multicolumn{2}{|c|}{ Total } \\
\hline & \multicolumn{2}{|c|}{$\begin{array}{c}\text { Tidak } \\
\text { malnutrisi }\end{array}$} & \multicolumn{2}{|c|}{ Malnutrisi } & \multirow[b]{2}{*}{$\mathbf{N}$} & \multirow[b]{2}{*}{$\%$} \\
\hline & $\mathbf{n}$ & $\%$ & $\mathbf{n}$ & $\%$ & & \\
\hline Baik & 45 & 55,6 & 16 & 19,8 & 61 & 75,3 \\
\hline Kurang & 16 & 19,8 & 4 & 4,9 & 20 & 24,7 \\
\hline Jumlah & 61 & 75,3 & 20 & 24,7 & 81 & 100 \\
\hline \multicolumn{7}{|c|}{$p=0,767$} \\
\hline
\end{tabular}

Sumber : Data Primer, 2019

Pada tabel 11 menunjukkan bahwa dari 81 responden terdapat tingkat kecukupan protein baik dengan kategori status gizi tidak malnutrisi pada siswa sekolah dasar sebanyak 45 responden (55,6\%) dan malnutrisi 16 responden (19,8\%) sedangkan responden yang tingkat kecukupan energy kurang dengan kategori status gizi tidak malnutrisi pada siswa sekolah dasar sebanyak 16 responden $(19,8 \%)$ dan malnutrisi sebanyak 4 responden $(4,9 \%)$.

Berdasarkan hasil uji statistik diperoleh nilai $\mathrm{p}=0,765<0,05$ sehingga hipotesis H0 diterima dan H1 di tolak berarti tidak ada hubungan antara tingkat kecukupan protein dengan status gizi siswa Sekolah Dasar Negeri 48 Kota Ternate Tahun 2019.

\subsubsection{Hubungan Kebiasaan Sarapan Pagi Dengan Status Gizi Anak Sekolah Dasar}

Tabel 12. Analisis Hubungan Kebiasaan Sarapan Dengan Status Gizi Siswa Di SD Negeri 48 Kota TernateTahun 2019

\begin{tabular}{|c|c|c|c|c|c|c|}
\hline \multirow{3}{*}{$\begin{array}{c}\text { Kebiasaan } \\
\text { Sarapan }\end{array}$} & \multicolumn{4}{|c|}{ Status Gizi } & \multicolumn{2}{|c|}{ Total } \\
\hline & \multicolumn{2}{|c|}{$\begin{array}{c}\text { Tidak } \\
\text { malnutrisi }\end{array}$} & \multicolumn{2}{|c|}{ Malnutrisi } & & \\
\hline & $\mathbf{n}$ & $\%$ & $\mathbf{n}$ & $\%$ & $\mathbf{N}$ & $\%$ \\
\hline Baik & 44 & 54,3 & 15 & 18,5 & 59 & 72,8 \\
\hline Kurang & 17 & 21,0 & 5 & 6,2 & 22 & 27,2 \\
\hline Jumlah & 61 & 75,3 & 20 & 24,7 & 81 & 100 \\
\hline
\end{tabular}

Sumber : Data Primer, 2019

Pada Tabel 12 menunjukkan bahwa dari 81 responden terdapat tingkat kebiasaan sarapan baik dengan kategori status gizi tidak malnutrisi pada siswa sekolah dasar sebanyak 44 responden $(54,3 \%)$ dan malnutrisi 15 responden (18,5\%) sedangkan responden yang tingkat kebiasaan sarapan kurang dengan kategori status gizi tidak malnutrisi pada siswa sekolah dasar sebanyak 17 responden $(21,0 \%)$ dan malnutrisi sebanyak 5 responden $(6,2 \%)$. 
Berdasarkan hasil uji statistil diperoleh nilai $\mathrm{p}=1,000<0,05$ sehingga hipotesis $\mathrm{H} 0$ diterima dan $\mathrm{H} 1$ di tolak berarti tidak ada hubungan antara kebiasaan sarapan dengan status gizi siswa Sekolah Dasar Negeri 48 Kota Ternate Tahun 2019.

\subsubsection{Hubugan Frekuensi Makanan Jajanan Dengan Status Gizi Anak Sekolah Dasar}

Tabel 13. Analisis Hubungan Frekuensi Makanan Jajan Dengan Status Gizi Siswa Di SD Negeri 48 Kota Ternate Tahun 2019

\begin{tabular}{|c|c|c|c|c|c|c|}
\hline \multirow{3}{*}{$\begin{array}{c}\text { Frekuensi Makanan } \\
\text { Jajan }\end{array}$} & \multicolumn{4}{|c|}{ Status Gizi } & \multirow{2}{*}{\multicolumn{2}{|c|}{ Total }} \\
\hline & \multicolumn{2}{|c|}{$\begin{array}{c}\text { Tidak } \\
\text { malnutrisi }\end{array}$} & \multicolumn{2}{|c|}{ Malnutrisi } & & \\
\hline & $\mathrm{n}$ & $\%$ & $\mathrm{n}$ & $\%$ & $\mathbf{N}$ & $\%$ \\
\hline Baik & 13 & 16,0 & 5 & 6,2 & 18 & 22,2 \\
\hline Kurang & 48 & 59,3 & 15 & 18,5 & 63 & 77,8 \\
\hline Jumlah & 61 & 75,3 & 20 & 24,7 & 81 & 100 \\
\hline
\end{tabular}

Sumber : Data Primer, 2019

Pada Tabel 13 menunjukkan bahwa dari 81 responden terdapat frekuensi makanan jajan baik dengan kategori status gizi tidak malnutrisi pada siswa sekolah dasar sebanyak 13 responden $(16,0 \%)$ dan malnutrisi 5 responden (6,2\%) sedangkan responden yang frekuensi makanan jajan kurang dengan kategori status gizi tidak malnutrisi pada siswa sekolah dasar sebanyak 48 responden $(59,3 \%)$ dan malnutrisi sebanyak 15 responden $(18,5 \%)$.

Berdasarkan hasil uji statistil diperoleh nilai $\mathrm{p}=1,000<0,05$ sehingga hipotesis H0 diterima dan H1 di tolak berarti tidak ada hubungan antara frekuensi makanan jajan dengan status gizi siswa Sekolah Dasar Negeri 48 Kota Ternate Tahun 2019.

\subsubsection{Hubungan Jumlah Uang Jajan Dengan Status Gizi Anak Sekolah Dasar}

Tabel 14. Analisis Hubungan Jumlah Uang Jajan Dengan Status Gizi Siswa Di SD Negeri 48 Kota Ternate Tahun 2019

\begin{tabular}{|c|c|c|c|c|c|c|}
\hline \multirow{3}{*}{$\begin{array}{l}\text { Jumlah Uang } \\
\text { Jajan }\end{array}$} & \multicolumn{4}{|c|}{ Status Gizi } & \multicolumn{2}{|c|}{ Total } \\
\hline & \multicolumn{2}{|c|}{$\begin{array}{c}\text { Tidak } \\
\text { malnutrisi }\end{array}$} & \multicolumn{2}{|c|}{ Malnutrisi } & \multirow[b]{2}{*}{$\mathbf{N}$} & \multirow[b]{2}{*}{$\%$} \\
\hline & $\mathbf{n}$ & $\%$ & $\mathbf{n}$ & $\%$ & & \\
\hline Baik & 60 & 74,1 & 20 & 24,7 & 80 & 98,8 \\
\hline Kurang & 1 & 1,2 & 0 & 0 & 1 & 1,2 \\
\hline Jumlah & 61 & 75,3 & 20 & 24,7 & 81 & 100 \\
\hline
\end{tabular}

Sumber : Data Primer, 2019

Pada Tabel 14 menunjukkan bahwa dari 81 responden terdapat jumlah uang jajan baik dengan kategori status gizi tidak malnutrisi pada siswa sekolah dasar sebanyak 60 responden $(74,1 \%)$ dan malnutrisi 20 responden $(24,7 \%)$ sedangkan responden yang jumlah uang jajan kurang dengan kategori status gizi tidak malnutrisi pada siswa sekolah dasar sebanyak 1 responden $(1,2 \%)$ dan dan tidak ada responden jumlah uang jajan kurang dan malnutrisi.

Berdasarkan hasil uji statistil diperoleh nilai $\mathrm{p}=1,000<0,05$ sehingga hipotesis H0 diterima dan $\mathrm{H} 1$ di tolak berarti tidak ada hubungan antara jumlah uang jajan dengan status gizi siswa Sekolah Dasar Negeri 48 Kota Ternate Tahun 2019.

\subsection{Pembahasan}

\subsubsection{Hubungan Tingkat Kecukupan Energi Dengan Status Gizi}

Energi merupakan hasil pembakaran dari zat makro yang meliputi karbohidrat, protein dan lemak. Manusia membutuhkan energi untuk mempertahankan hidup, menunjang pertumbuhan dan melakukan aktifitas fisik. Kebutuhan energi seseorang menurut WHO, adalah konsumsi energi dari makanan yang diperlukan untuk menutupi pengeluaran energi seseorang bila mempunyai ukuran komposisi tubuh dan aktifitas (Almatsier, 2010).

Berdasarkan hasil uji statistil diperoleh nilai $\mathrm{p}=0,695<0,05$ sehingga hipotesis $\mathrm{H} 0$ diterima dan H1 di tolak berarti tidak ada hubungan antara tingkat kecukupan energi dengan status gizi siswa Sekolah Dasar Negeri 48 Kota Ternate Tahun 2019. 
Hasil penelitian ini tidak sejalan dengan penelitian yang dilakukan oleh Fitriani Valentine Limpeleh tentang hubungan antara asupan energi dengan status gizi anak usia sekolah di kompleks pasar 45 Kota Manado tahun 2014 dari hasil uji statistik antara asupan energi dengan status gizi diperoleh nilai $p=0,032<0,05$ yang berarti bahwa ada hubungan yang bermakna antara asupan energi dengan status gizi anak usia sekolah (Limpelah, 2014).

Kebiasaan makan berperan penting dalam menetukan tingkat status gizi individu maupun kelompok. Untuk memenuhi kebutuhan energi dan zat gizi, pada anak usia pertumbuhan dan perkembangan maka dibutuhkan 5 kali waktu makan, yaitu makan pagi (sarapan), makan siang, makan malam dan dua kali makan selingan. Pola makan yang sehat juga dapat mempengaruhi pertumbuhan dan perkembangan motorik pada anak. Pola makan sehat yang dimaksud meliputi jenis makanan yang bergizi, tingkat konsumsi energi diperhatikan, serta porsi makanan yang dikonsumsi anak, kebutuhan dan asupan gizi berasal dari konsumsi makanan sehari-hari. Asupan gizi yang tidak seimbang akan mempengaruhi status gizi.

Dari hasil penelitian di SD Negeri 48 Kota Ternate Tahun 2019 dapat dilihat bahwa siswa banyak mengonsumsi zat gizi yang mengandung energi, energi yang dikonsumsi pada pagi hari sebelum berangkat ke sekolah dalam hal ini sarapan, makanan dan minuman yang di konsumsi dan mengandung zat energi adalah energen, susu dan teh.

\subsubsection{Hubungan Tingkat Kecukupan Protein Dengan Status Gizi}

Protein dikatakan sebagai zat pembangun atau pertumbuhan karena protein merupakan bahan pembentuk jaringan baru dalam tubuh. Protein berfungsi sebagai zat pengatur karena protein merupakan bahan pembentuk enzim dan hormon yang berperan sebagai pengatur dalam metabolisme tubuh. Sedangkan fungsi protein juga mempertahankan daya tahan tubuh terhadap serangan penyakit tertentu karena protein merupakan komponen pembentuk antibodi. (Almatsier, 2007).

Bahan makanan hewani merupakan sumber protein yang baik, dalam jumlah maupun mutu, seperti telur, susu, daging, unggas, ikan, dan kerang. Sumber protein nabati adalah kacang kedelai dan hasilnya, seperti tempe dan tahu, serta kacang-kacangan lain. Kacang kedelai merupakan sumber protein nabati yang mempunyai mutu atau nilai biologi tertinggi. Seperti telah dijelaskan semula protein kacang-kacangan terbatas dalam asam amino metionin. kondisi ini menunjukan bahwa responden baik dalam mengatur konsumsi makanan yang masuk dalam tubuhnya. Sering dikonsumsi adalah ikan dan daging ayam (Pudjiadi, 2000).

Berdasarkan hasil uji statistik diperoleh nilai $\mathrm{p}=0,765<0,05$ sehingga hipotesis H0 diterima dan H1 di tolak berarti tidak ada hubungan antara tingkat kecukupan protein dengan status gizi siswa Sekolah Dasar Negeri 48 Kota Ternate Tahun 2019. Hasil penelitian tersebut sejalan dengan penelitian yang dilakukan Batubara tahun 2019 di Sekilah Dasar Dinamika Indonesia, Kota Bekasi dengan nilai $\mathrm{p}=0.616$ yang artinya tidak ada hubungan antara asupan protein dengan status gizi Batubara, FR 2019).

Protein yang diperlukan untuk pertumbuhan yang normal tergantung dari zat gizi yang dimakan seperti sebagaimana mudahnya zat tersebut dapat dicerna, distribusi, asam amino proteinya. Dari hasil penelitian di SD Negeri 48 Kota Ternate Tahun 2019 terdapat siswa yang banyak mengonsumsi protein, makanan yang sering dikonsumsi siswa ialah ikan goreng, telur goreng, dan ayam goreng terdapat 61 siswa yang memiliki pemenuhan gizi protein baik.

\subsubsection{Hubungan Kebiasaan Sarapan Dengan Status Gizi}

Sarapan pagi adalah suatu kegiatan yang penting sebelum melakukan aktivitas fisik disekolah. Ada dua manfaat yang bisa diambil dari srapan pagi. Pertama sarapan pagi dapat menyediakan karbohidrat yang siap digunakan untuk menungkatkan kadar gula darah. Dengan kadar gula darah yang terjamin normal, maka konsentrasi bisa lebih baik sehingga berdampak posistif pada aktifitas anak di sekolah. Kedua, pada dasarnya sarapan pagi akan memberikan kontribusi penting akan beberapa gizi yang diperlukan tubuh seperti protein, lemak, vitamin dan mineral. Ketersediaan zat gizi ini bermanfaat untuk fungsingnya proses fisiologis dalam tubuh (Khomsan, 2004)

Berdasarkan hasil uji statistik diperoleh nilai $p=1,000<0,05$ sehingga hipotesis H0 diterima dan H1 di tolak berarti tidak ada hubungan antara kebiasaan sarapan dengan status gizi siswa Sekolah Dasar Negeri 48 Kota Ternate Tahun 2019. Hasil penelitian ini tidak sejalan dengan penelitian yang dilakukan oleh Jurianto tentang Penerapan model edukasi gizi terhadap perilaku sarapan pada anak sekolah dasar tahun 2018, dari hasil penelitian terdapat $16-59 \%$ anak sekolah di Indonesia tidak terbiasa sarapan. Anak sekolah yang terbiasa sarapan 44,6\% dengan tingkat konsusmsi energi $<15 \%$ 
AKG, 70\% dengan mutu gizi sarapan yang tergolong buruk dengan hanya minum air/kopi/teh atau dengan (satu) 1 potong kue kecil (Jurianto dkk, 2018).

Hasil penelitian MC Cormick, dkk tahun 2010 pada anak Sekolah di Fiji menunjukkan bahwa semakin sering anak melewatkan saraoan makan risiko terjadinya kegemukan menjadi lebih tinggi. Pada anak yang tidak sarapan kemungkinan akan mengurangi rasa lapar dengan membeli makanan jajanan yang justru kandungan gizinya kurang seimbang, Apabila hal ini terjadi terus menerus maka akan mempengaruhi prestasi belajar anak. Selain itu anak yang tidak sarapan pagi cenderung lebih sering mengonsumsi makanan jajan untuk memenuhi kebutuhan energinya. Jika makanan yang dikonsumsi tidak memperhatikan nilai gizi, keamanana dan kebersihanya maka ini akan berpengaruh pada kesehatan.

\subsubsection{Hubungan Frekuensi Makanan Jajanan Dengan Status Gizi}

Makanan jajan merupakan bagian tidak terpisahkan dari kehidupan anak sekolah dasar. Konsumsi makanan jajan anak turut mempengaruhi kontribusi dan kecukupan energi dan zat gizinya yang berujung pada status gizi anak. Suhardjo (2003) menyebutkan bahwa kebiasaan jajan merupakan istilah untuk menggambarkan kebiasaan dan perilaku yang terhubung dengan makan dan makanan seperti frekuensi makan, jenis makanan, kepercayaan terhadap makanan (pantangan), dan cara pemilihan makanan.

Berdasarkan hasil uji statistil diperoleh nilai $\mathrm{p}=1,000<0,05$ sehingga hipotesis H0 diterima dan $\mathrm{H} 1$ di tolak berarti tidak ada hubungan antara frekuensi makanan jajan dengan status gizi siswa Sekolah Dasar Negeri 48 Kota Ternate Tahun 2019. Hasil penelitian ini tidak sejalan dengan penelitian yang dilakukan oleh Nuryani, dkk tahun 2014, tentang kebiasaan jajan berhubungan dengan status gizi siswa anak sekolah di Kabupaten Gorontalo, dari hasil uji statistik antara frekuensi makanan jajan dengan status gizi siswa diperoleh nilai $p=0,030>0,05$ yang berarti bahawa tidak ada hubungan antara frekuensi makanan jajan dengan status gizi siswa (Nuryani, dkk 2014).

\subsubsection{Hubungan Jumlah Uang Jajan Dengan Status Gizi}

Uang jajan merupakan faktor yang mempengaruhi pengeluaran konsumsi siswa, dengan ratarata pendapatan uang jajan yang berbeda-beda dari setiap siswa, yang diterimanya setiap hari. Sebagian besar siswa mengandalkan uang jajan yang didapatnya untuk digunakan dalam berkonsumsi. Sehingga uang jajan dan pengeluaran konsumsinya berbanding lurus (Syahrina, 2008).

Berdasarkan hasil uji statistik diperoleh nilai $\mathrm{p}=1,000<0,05$ sehingga hipotesis $\mathrm{H} 0$ diterima dan H1 di tolak berarti tidak ada hubungan antara jumlah uang jajan dengan status gizi siswa Sekolah Dasar Negeri 48 Kota Ternate Tahun 2019. Penelitian ini tidak sejalan dengan penelitian yang dilakukan oleh Rosyidah, dkk (2015), dari hasil uji statistik antara jumlah uang jajan dengan status gizi siswa diperoleh nilai $p=0,000<0,05$ yang berarti bahwa terdapat hubungan anatara jumlah uang jajan dengan status gizi siswa (Rosyidah, 2015).

Hal ini disebabkan karena sebagian besar siswa memiliki uang jajan yang tinggi sehingga besar uang jajan yang dimiliki anak sekolah menentukan daya beli terhadap makanan jajan selama anak tersebut berada disekolah. Anak-anak yang terbiasa melewatkan sarapan beresiko 3 kali lebih tinggi untuk mengkonsumsi jajanan dan sulit mengontrol nafsu makan mereka sehingga menyebabkan obesitas (Kral dkk, 2011). Apalagi 95\% anak diberi uang saku oleh orang tuanya sehingga kemungkinan untuk membeli makanan jajanan lebih tinggi (Depkes RI, 2011).

\section{PENUTUP}

Berdasarkan hasil penelitian tentang Hubungan Tingkat Kecukupan Gizi dengan Status Gizi Anak Sekolah Dasar Negeri 48 Kota Ternate Tahun 2019 disimpulkan bahwa :

1. Tidak ada hubungan yang bermakna antara tingkat kecukupan energi dengan status gizi siswa SD Negeri 48 Kota Ternate Tahun 2019 dengan nilai $p$ value = 0,695

2. Tidak ada hubungan yang bermakna antara tingkat kecukupan protein dengan status gizi siswa SD Negeri 48 Kota Ternate Tahun 2019 dengan nilai $p$ value $=0,767$

3. Tidak ada hubungan yang bermakna antara kebiasaan sarapan dengan status gizi siswa SD Negeri 48 Kota Ternate Tahun 2019 dengan nilai $p$ value $=1,000$

4. Tidak ada hubungan yang bermakna antara frekuensi makanan jajan dengan status gizi Ansiswi SD Negeri 48 Kota Ternate Tahun 2019 dengan nilai $p$ value $=1,000$

5. Tidak ada hubungan yang bermakna antara jumlah uang jajan dengan status gizi siswa SD Negeri 48 Kota Ternate Tahun 2019 dengan nilai $p$ value $=1,000$ 
Berdasarkan hasil analisis maka saran yang dapat disampaikan adalah diharapkan kepada orang tua untuk meningkatkan pengetahuan tentang gizi terutama tentang memilih jajanan serta mempraktekanya dalam kehidupan sehari-hari agar menjadi perilaku yang dapat ditiru oleh anak, membiasakan anak sarapan pagi sebelum berangkat ke sekolah dan membimbing anak dalam memilih jajanan yang sehat. Bagi peneliti selanjutnya, adanya keterbatasan sampel pada penelitian ini, maka kepada peneliti lain dapat melanjutkan penelitian dengan jumlah sampel yang lebih banyak, dan variabel yang berbeda, juga dengan analisis uji statitik yang berbeda, bisa juga penelitian dilanjutkan dengan melihat kasus dan kontrol ataupun desaign cohort.

\section{DAFTAR PUSTAKA}

Almatsier Sunita. 2010. Prinsip Dasar Ilmu Gizi . Jakarta: Penerbi Gramedia Pustaka Utama.

Ari Istiany, Rusilanti. 2013. Gizi Terapan. Bandung.

Batubara, Frisca Ranauli. 2019. Hubungan Asupan Energi Dan Protein Terhadap Status Gizi Siswa 1012 Tahun Di Sekolah Dasar Dinamika Indonesia, Kecamatan Bantargebang, Kota Bekasi. Jurnal Ilmiah WIDYA Volume 6 No 1.

Damayanti, Didit Muhilal. 2006. Gizi Seimbang Untuk Anak Usia Sekolah Dasar. Jakarta: EGC.

Depkes RI. Riset Kesehatan Dasar 2013. Diunduhdari:http://www.litbang.depkes.go.id/sites/download /buku_laporan/lapnas_riskesdas2013/laporan_riskesdas_2013.pdf.

Departemen Kesehatan RI. 2011. Jejaring Infomasi Pangan dan Gizi Edisi II. Jakarta: Depkes RI.

Devi, N. Gizi Anak Sekolah. 2011. PT Kompas Media Nusantara : Jakarta.

Djamarah, Syaiful Bahri. 2006. Strategi Belajar Mengajar. Jakarta: Penerbit Rineka Cipta.

Dinas Kesehatan Kota Ternate. 2016-2017. Bidang Kesehatan Keluarga Rekapitulasi Hasil Pemantauan Status Gizi Peserta Didik Di SD Tahun.

Ilyatun, M Rizal, Karina. 2014. Kebiasaan Sarapan, Status Gizi, dan Kualitas Hidup Anak SD Bosowa Bina Insari Bogor; jurnal Gizi dan pangan, hlm. 1-3.

Jurianto Gambir, Nopriantini, 2018. Penerapan Model Edukasi Gizi Terhadap Perilaku Sarapan Pada Anak Sekolah Dasar. Jurusan Gizi, Politeknik Kesehatan Kementrian Kesehatan Pontianak. Jurnal Vokasi Kesehatan, Volume 4 No 2.

Kementerian Kesehatan RI. 2013. Riset Kesehatan Dasar. Jakarta: Kementerian Kesehatan RI;

Khomsan, Ali. 2004. Pangan Dan Gizi untuk Kesehatan, Jakarta : Penerbit Raja Grasindo Prasada.

Kral, Linda M Whiteford, Moonseong Heo, Myles S Faith. 2011. Effects Of Eating Breakfasr Compared With Skipping Breakfast On Rating Of Appetite And Intake At Subsequent Meals In 8-to 10-yOld Childern. The American Journal of Clinical Nutrition, 93 (2),284-291.

Limpelah, Fitriani. 2014. Hubungan Antara Energi Dengan Status Gizi Anak Usia Sekolah Di Kompleks Pasar 45 Kota Manado. Fakultas Kesehatan Masyarakat Universitas Sam Ratulangi Manado.

Mc Cormick, T, Thomas J.J., Bainivualiku A., Khan A.N., \& Becker A.E. 2010. Breakfast Skipping As A Risk Correlate Of Overweight Adolescent Obesity In Scholing-Going Ethnic Fijian Nutrition. 19(3) 372.

Nuryani, Rahmawati. 2018. Kebiasaan Jajan Berhubungan Dengan Status Gizi Siswa Anak Sekolah Di kabupaten Gorontalo. Jurnal Gizi Indonesia (The Indonesian Journal Of Nutrition), 6 (2), 2018 e-ISSN : 2338-3119, p-ISSN: 1858-4942

Pudjiadi, S. 2000. Ilmu Gizi Klinis pada Anak. Jakarta: Balai Penerbit FKUI.

Riset Kesehatan Dasar (Riskesdas). 2013. Badan Penelitian dan Pengembangan Kesehatan Kementrian RI tahun 2013.

Rosyidah, Zia \& Dini Riris Andrias. 2015. Jumlah Uang Saku Dan Kebiasaan Melawatkan Sarapan Berhubungan Dengan Status Gizi Lebih Anak Sekolah Dasar. Jurnal Mrdia Gizi Indonesia Vol 10 No 1 Januari-Juni 2015 Hlm1-6.

Suhardjo. 2003. Berbagai Cara Pendidikan Gizi, Jakarta: Penerbit PT. Bumi Aksara.

Suryabrata, Sumadi. 2010. Psikologi Pendidikan. Jakarta: Penerbit Raja Grafindo Persada.

Syahrina, Ade. 2008. Faktor - Faktor Yang Mempengaruhi Konsumsi Mahasiswa UNHAS Kota Makassar. Skripsi Ekonomi Universitas Hasanuddin. 
World Health Organization. 2018. Who int. Micronutrient Advantages. [Online] World Health Organization Global, 2012. http://www.who.int/nutrition/topics/ida/en. Diakses pada tanggal 7 april 2018. 